Research Article

\title{
The Comprehensive Comparison of Thermal and Physical-Mechanical Properties of the Recycled Rubber and Plastic Roofing Tiles versus Roofing Tiles Made with Different Traditional Materials
}

\author{
Rosana Gaggino $\mathbb{D}^{\mathrm{D}},{ }^{1}$ Jerónimo Kreiker ${ }^{(D)},{ }^{1}$ Celina Filippín, ${ }^{2}$ María Paz Sánchez Amono, ${ }^{1}$ \\ Julián González Laría, ${ }^{1}$ and Lucas Ernesto Peisino ${ }^{1}$ \\ ${ }^{1}$ Experimental Economical Housing Center (CEVE), National Council of Scientific and Technical Research (CONICET), \\ Economical Housing Association (AVE), and Córdoba, Argentina \\ ${ }^{2}$ National Council of Scientific and Technical Research (CONICET), Santa Rosa, La Pampa, Argentina \\ Correspondence should be addressed to Rosana Gaggino; directora@ceve.org.ar
}

Received 14 August 2017; Revised 9 November 2017; Accepted 27 November 2017; Published 29 March 2018

Academic Editor: John Mander

Copyright (c) 2018 Rosana Gaggino et al. This is an open access article distributed under the Creative Commons Attribution License, which permits unrestricted use, distribution, and reproduction in any medium, provided the original work is properly cited.

The objectives of this research were to estimate the thermal transmittance and some physical-mechanical properties of a housing cover built with roofing tiles made from recycled plastics and rubber and compare them with three other traditional solutions for housing cover: ceramic roofing tiles, concrete roofing tiles, and zinc sheets. This roofing tile has technical advantages over the others, due to its higher thermal insulation, higher resistance to freezing, higher resistance to hail, higher flexural resistance, lower specific weight, and lower water absorption, with lower cost than the traditional glazed black ceramic roofing tile. And it is also friendlier to the environment.

\section{Introduction}

1.1. Brief History of the Technological Development of Tiles. The origins of the roofing tiles go back to Antiquity. Towards the year $2000 \mathrm{BC}$, the Mesopotamian civilizations around the Tigris and Euphrates Rivers began to make clay tiles (ceramic), which behaved much better against the rain than the roofs made of straw, branches, and leaves that were used before. Due to its technical qualities of good mechanical resistance, impermeability, and ease of placement, its use soon spread throughout the Mediterranean being widely used by Greeks and Romans. Almost at the same time, they began to be manufactured in China $[1,2]$.

Over time, roofing tiles of different shapes and styles were made, and their manufacturing process ceased to be manual to be mechanical.

During the 19th century, the first concrete roofing tile appeared in Bavaria. At this time, the use of mixtures with pigments to manufacture tiles with different colors began [3]. This roofing tile had these advantages with respect to the ceramic tile: a higher durability and resistance, lower cost, ease of placement, and greater variety of colors. An inconvenience of the concrete roofing tile is that it is heavier than the ceramic one, so it needs a support structure of greater dimensions and cost.

The roofing tile always means good taste and distinction. Formerly the roofing tile was used exclusively to cover the houses of the high society people, but at present the roofing tiles are much more affordable and can be found of all prices and varieties. However, it still happens that a house covered with roofing tiles in addition to being highly valued from the aesthetic point of view is considered to be a more expensive housing, thus increasing its value in the market.

Since the last century, the zinc sheet has been used in cover of houses. Its advantages are low price, water tightness, and resistance to impact (e.g., the hail). Disadvantages are its 
lower thermal and acoustic insulation compared to other traditional components for house covers and the moisture condensation problem. For this reason, it is mainly used in constructions of economic type. In cases where it is applied in more expensive constructions, it is always with a thermal insulating ceiling.

Since the end of the 20th century, the plastic roofing tile has been used as a high-tech building material. Its technical advantages are its better thermal insulation, variety of colors, ease of installation, and resistance to corrosion. It has not had the same success as the ceramic or the concrete roofing tile because its duration is limited, and it has less resistance to ultraviolet radiation and to hail [4].

In the history of the technological development of roofing tiles and sheets, until the end of the second millennium, the objectives were technical and economic (rainresistant, hail-resistant, flexural-resistant, and low-cost).

1.2. Changes in the Technological Development of the Roofing Tiles with the New Paradigm of Sustainable Construction. Only from the penultimate decade of the twentieth century were taken into account ecological objectives to produce constructive components for house cover, including reducing the consumption of natural resources and the impact on the environment. The change was introduced by the new concept of sustainable construction.

The sustainable construction seeks to enable future generations not to be harmed by the construction human activity (until the present destruction of the environment). According to Kibert [5], we ought to build some premises that we could consider ecological and are listed below:

(i) Conservation of resources

(ii) Reuse of resources

(iii) Use of recyclable and renewable resources in construction

(iv) Considerations regarding the life cycle of the raw materials used, with the corresponding prevention of residues and emissions

(v) Reduction in energy use

(vi) Increased quality in materials, buildings, and urbanized environment

(vii) Environmental protection

(viii) Creating a healthy and nontoxic environment in buildings

The traditional technologies used to manufacture constructive components cause environmental impact, to a greater or lesser extent. They all involve the extraction of raw materials, in some cases nonrenewable resources.

In the last two decades, different countries have begun to manufacture constructive elements that have a minor impact on the environment, replacing natural raw materials by waste from the industry.

Research on roofing tiles with recycled materials hardly takes a few years: for example, the slate made with a plastic mixture of PVC, CPVC, PVDC, ABS, ASA, and EVA patented in Europe [6], the nylon sheets that simulate roofing tiles in the United States [7] and in Europe [8]; the roofing tiles developed in Brazil with long-life packages [9] and the thermomechanical properties determinations in recycled materials [10].

Adhering to the premise of protecting the environment, the Economical Experimental Housing Center in Córdoba, Argentina, has developed different constructive elements that are more ecological than the traditional ones, made from waste. A research project started in 2010 has developed the different components of a house cover (roofing tile, valance, and ridge) using entirely recycled materials such as plastics from the industry and rubber from end of life tires (ELTs).

In previous publications, this research team has described the methodology and the results achieved in the development work about roofing tiles made form recycled materials [11]. In this paper, the purpose is to compare the thermal performance of these components with that of other traditional ones that are used for the same application in our country, such as zinc sheets and ceramic and concrete roofing tiles, in relation to the costs and benefits of each one.

The technology developed in CEVE collaborates in the decontamination of the environment, since it only uses residues that are largely buried in municipal landfills, without any utility, or accumulated and burned in garbage dumps, causing degradation of the environment.

1.3. Availability of the Recycled Materials Used in This Technology. Large quantities of plastic waste are available. According to data provided in 2015 by the Ministry of Health and Environment of the Nation, Argentina produces $1 \mathrm{~kg}$ of garbage per day per person, which is equivalent to $12,325,000$ tons of garbage per year. Plastic wastes constitute $13.3 \%$ of the total weight (1,639 tons/year) [12]. Most of plastics are no biodegradable materials, so nature cannot absorb them as other waste. The low-density polyethylene (LDPE) bags take 150 years to degrade in contact with natural agents [13].

Large quantities of rubber from ELTs are also available. According to the National Institute of Industrial Technology data for 2012, more than 100,000 tons are generated annually [14].

The ELTs, which accumulate in landfills, produce visual contamination, have a high flammability, and are not degradable. They are the ideal refuge for insects, rodents, and reptiles, so their accumulation favors the spread of dengue and other diseases transmitted by mosquitoes. It is proven that when they burn, they emit carcinogenic substances. Only a fraction of ELTs are recycled to produce heat energy in special furnaces such as those used in the cement industry, which have adequate filters to avoid producing atmospheric pollution [15].

1.4. Comparison of Constructive Components in the Local Construction Market. In the province of Córdoba, Argentina, roofing tiles and zinc sheets have a widespread use for the execution of house covers. According to the National Census 
of Population, Homes and Houses conducted in the Province of Córdoba in 2010, there are a total of 414,237 households. 35,070 households use roofing tiles or slate (8.37\%); and 18,181 households use zinc sheets (4.38\%), see Table 1 and Figure 1 [16].

\section{Objectives of This Work}

In this work, we determined the thermal performance of a house cover built with roofing tiles made from recycled rubber and plastic, and it is compared with traditional house covers systems (with zinc sheets, concrete, and ceramic roofing tiles). Moreover, we determine the physical-mechanical properties of the roofing tiles made from recycled rubber and plastic. Then, comparison with traditional roofing systems was carried out.

\section{Experimental}

3.1. Applied Methodology. The design of a traditional constructive system for a house cover with a wooden structure was carried out, and the calculation of the thermal transmittance, $K$, was performed for the climatic zone of Córdoba, which is classified as a Zone III A (Temperate dry), according to Argentine Institute of Normalization and Certification (IRAM) Standard 11603/96, using four different types of constructive elements: zinc sheets, concrete tiles, ceramic tiles, and CEVE roofing tiles [11] made from recycled rubber and plastics.

See in Figure 2 the bioclimatic zones of Argentina, with the location of the province of Córdoba.

Subsequently, the comparison was made between the thermal transmittance of the different alternatives and the verification of compliance with the standard set in our country by the IRAM Standard 11,605, required by Argentine national law number 13,059. The goal was to meet Level B (average level). The CEEMA2CON program developed by Gonzalo (2003) [17] was used for calculations.

A comparison was also made between the other technical properties and the cost of each one of the alternatives, in order to have the necessary tools when selecting one of them to design a home.

\subsection{Description of the Construction Technology Used in the} Prototype. For this work, it was used a prototype of house with four different covers (Figure 3). The four alternatives were built with the same technology; the only difference between them was the type of constructive element used in the house covers.

The construction system used on these sloped roofs is a traditional type and consists of these elements: a structure of $3^{\prime \prime} \times 6^{\prime \prime}$ saligne pine straps, $1.5^{\prime \prime} \times 2^{\prime \prime}$ saligne pine ribbons, $6 \mathrm{~mm}$ pine plywood ceiling, $40 \mathrm{~mm}$ expanded polystyrene thermal insulation layer, $40 \mathrm{~kg} / \mathrm{m}^{2}$ waterproof $\mathrm{Wichi}{ }^{\circledR}$ membrane with aluminum, $1^{\prime \prime} \times 2^{\prime \prime}$ pine cleats, $25 \mathrm{~mm}$ air chamber between roofing tiles and pine cleats, and different constructive elements for cover (zinc sheets, ceramic, concrete, or rubber and plastic roofing tiles), see Figures 4 and 5 .
TABle 1: Types of house cover used in the province of Córdoba, Argentina [16].

\begin{tabular}{lc}
\hline $\begin{array}{l}\text { Prevailing material of the roof covering and } \\
\text { presence of ceilings }\end{array}$ & $\begin{array}{c}\text { Total } \\
\text { households }\end{array}$ \\
\hline Total & 414.237 \\
Asphalt roof or membrane with ceiling & 63.159 \\
Asphalt roof or membrane without ceiling & 23.513 \\
Flooring tile or slab with ceiling & 143.408 \\
Flooring tile or slab without ceiling & 122.169 \\
Slate or roofing tile with ceiling & 23.985 \\
Slate or roofing tile without ceiling & 11.085 \\
Zinc sheet with ceiling & 8.327 \\
Zinc sheet without ceiling & 9.854 \\
Asbesto cement or plastic sheet with ceiling & 1.009 \\
Asbesto cement or plastic sheet without ceiling & 1.315 \\
Cardboard sheet with ceiling & 72 \\
Cardboard sheet without ceiling & 229 \\
Cane, table, or straw with clay, single straw & 152 \\
with ceiling & \\
Cane, table, or straw with clay, single straw & 652 \\
without ceiling & 2.627 \\
Others with ceiling & 2.681 \\
Others without ceiling &
\end{tabular}

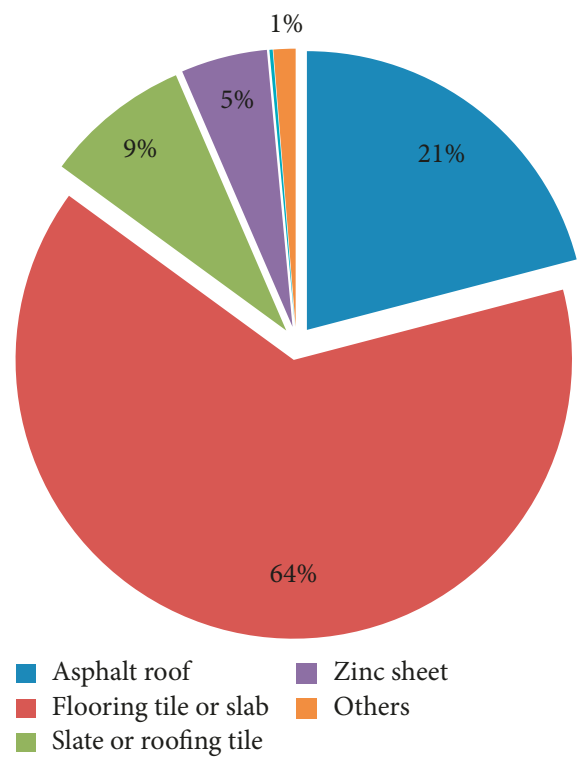

FIGURE 1: Comparative graphic of the types of house cover used in the province of Córdoba, Argentina [16].

\subsection{Description of the Technology Used for the Production of Roofing Tiles Made from Recycled Material Developed by CEVE}

3.3.1. Materials. Recycled materials of two types were used: crushed rubber from ELTs with particle size of 1-2 mm and LDPE from hoses, drums, and discarded pipes, in the form of pellets $2-3 \mathrm{~mm}$ long.

3.3.2. Equipment. A single-screw extruder made by $\mathrm{MJ}$ (Martin Jimenez) was used to process the rubber and plastic mixture. This machine has three heating zones (600 watt, 


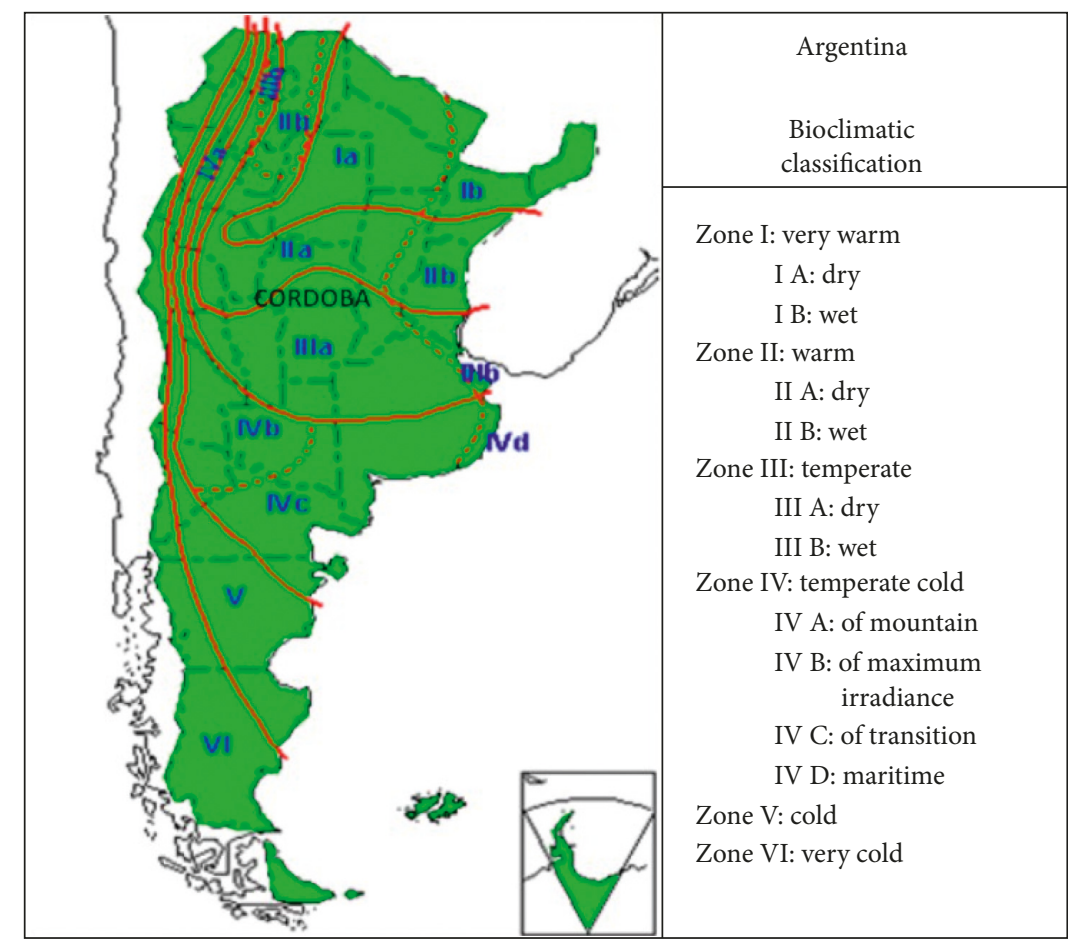

FIGURE 2: Bioclimatic classification of the zones of Argentina according to IRAM Standard 11603/96 [17].

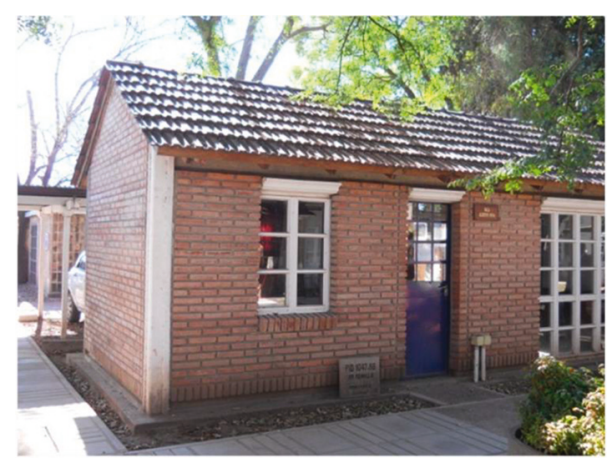

(a)
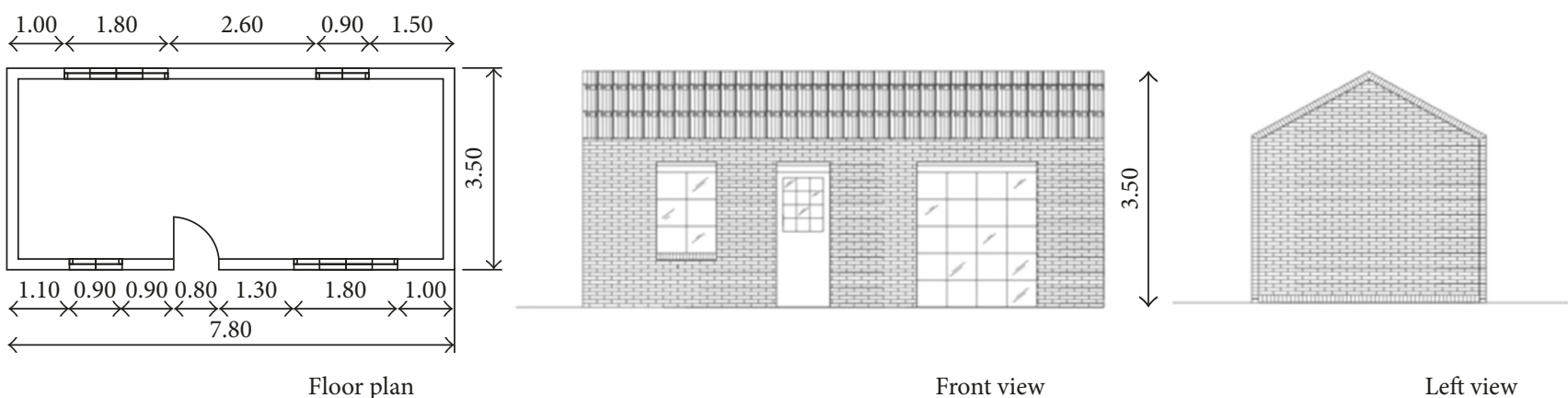

Floor plan

(b)

Figure 3: Picture of the prototype used to carry out this study (a). Plant and views of this prototype (b).

$220 \mathrm{~V}$ resistors), and the rotational velocity is $130 \mathrm{rpm}$. The screw diameter (d) is $40 \mathrm{~mm}$, and $\mathrm{L} / \mathrm{d}$ ratio is 25 .

To press the hot paste, the MJ pneumatic pressing machine was used. The maximum pressure is 20 tons.
3.3.3. Process. The material was mixed in a horizontal mixer for 2 minutes and then added to the hopper of the extruder. The screw was heated in a gradient between $250^{\circ} \mathrm{C}$ and $270^{\circ} \mathrm{C}$; the hot and melted material was placed in the mold 


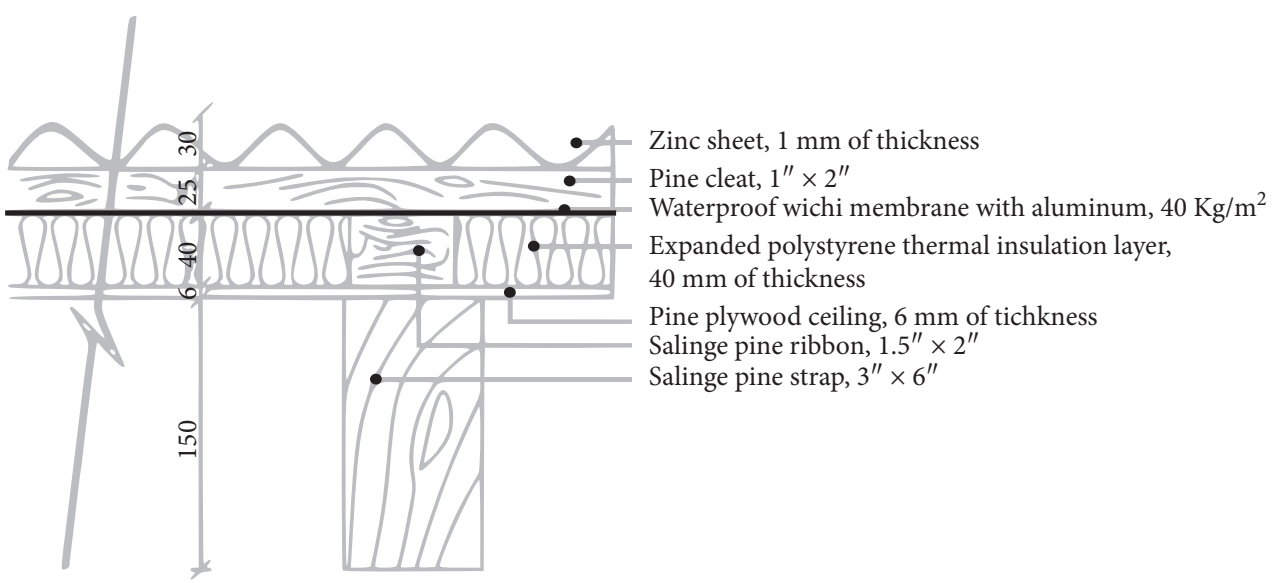

(a)

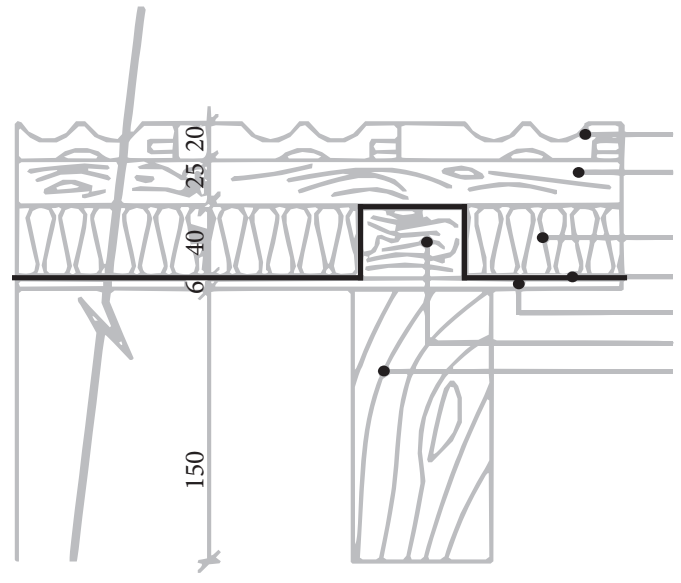

Ceramic tile, $15 \mathrm{~mm}$ of thickness on average Pine cleat, $1^{\prime \prime} \times 2^{\prime \prime}$

Expanded polystyrene thermal insulation layer, $40 \mathrm{~mm}$ of thickness

Waterproof wichi membrane with aluminum, $40 \mathrm{Kg} / \mathrm{m}^{2}$

Pine plywood ceiling, $6 \mathrm{~mm}$ of tichkness

Salinge pine ribbon, $1.5^{\prime \prime} \times 2^{\prime \prime}$

Salinge pine strap, $3^{\prime \prime} \times 6^{\prime \prime}$

(b)

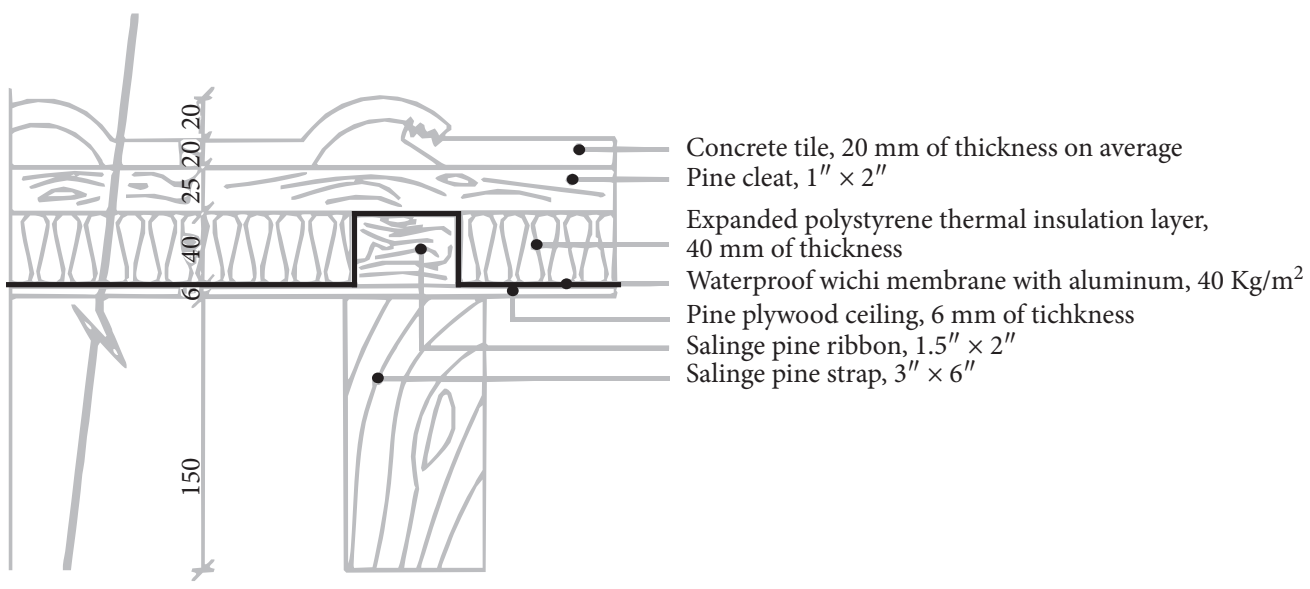

(c)

Figure 4: Continued. 


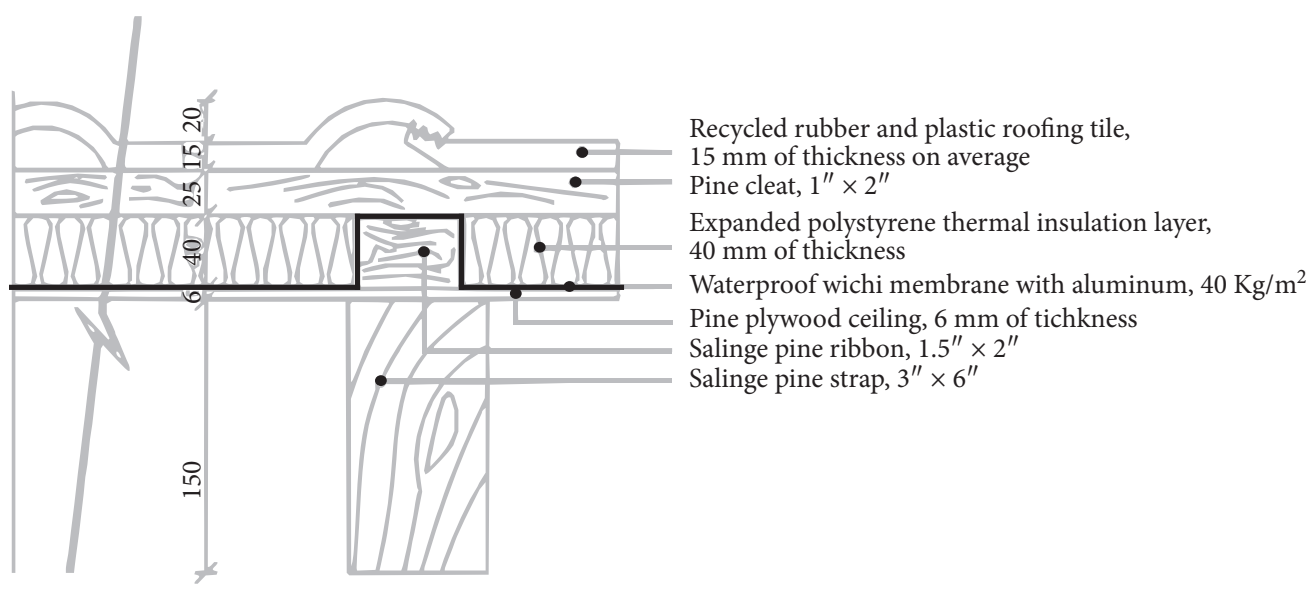

(d)

Figure 4: Constructive detail of case 1 (a), case 2 (b), case 3 (c), and case 4 (b).

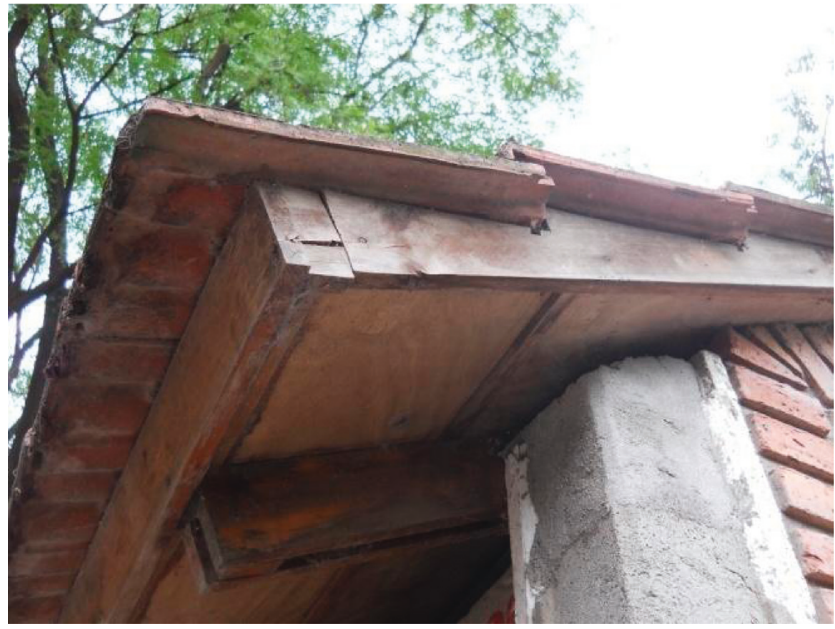

(a)

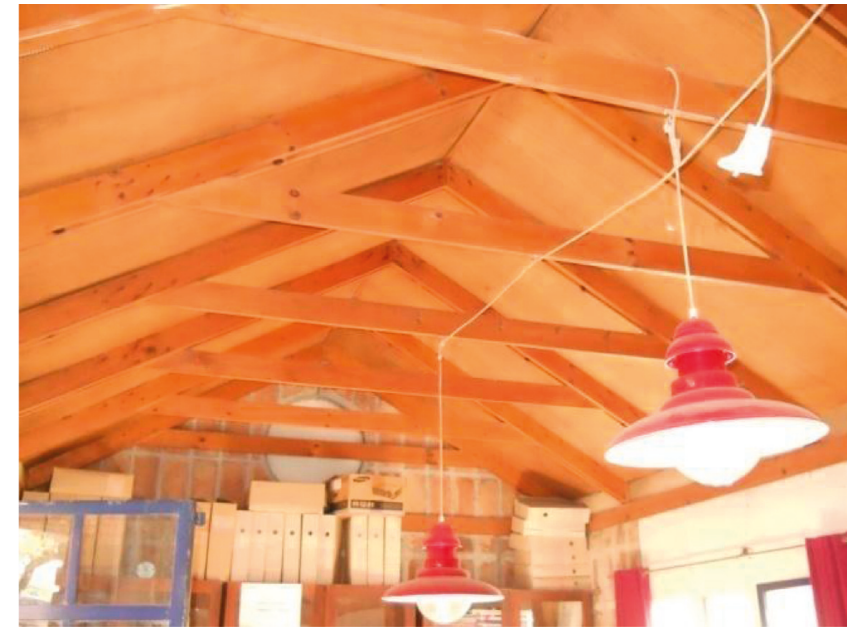

(b)

FIGURE 5: Picture with a detail of the cover (a) and picture with the interior of the house (b).

with manual aid for material distribution, and a pressure of 20 tons was applied for 4 minutes. The molded roofing tile was then removed from the mold and cooled in a frame to avoid deformation. See manufacturing sequence in Figure 6.

Figure 6(b) shows the melted material leaving from die of extruder machine. In this point, we detected the emission of smoke, due to the processing of the LDPE and rubber at high temperatures $\left(270^{\circ} \mathrm{C}\right)$. Therefore, the manufacturing process must be carried out under extractor equipped with filters for volatile organic compounds (particles filter and activate charcoal filter).

\section{Results}

4.1. Comparison of Test Results. A comparison has been made between the properties of the roofing tiles developed by CEVE made from recycled materials and other traditional roofing elements in our country such as zinc sheets and concrete and ceramic tiles acquired from manufacturers of these products in the city of Córdoba, Argentina.
The properties of the constructive elements have been established in the following standardized laboratories of Argentina:

(i) Laboratory of the Center for Research, Development and Transfer of Materials and Quality-CINTEMAC, National Technological University-UTN, Córdoba Regional Faculty.

(ii) Laboratory of Structures of the Faculty of Exact, Physical and Natural Sciences of the National University of Córdoba-FCEFyN, UNC.

The technical properties of the constructive elements are shown in Table 2.

\subsubsection{Discussion of Test Results}

(1) Weight per unit area: the roofing tile made from recycled materials has a weight per $\mathrm{m}^{2} 33 \%$ higher than the zinc sheet, $40.3 \%$ lower than the concrete roofing tile, and $51.5 \%$ lower than the ceramic 


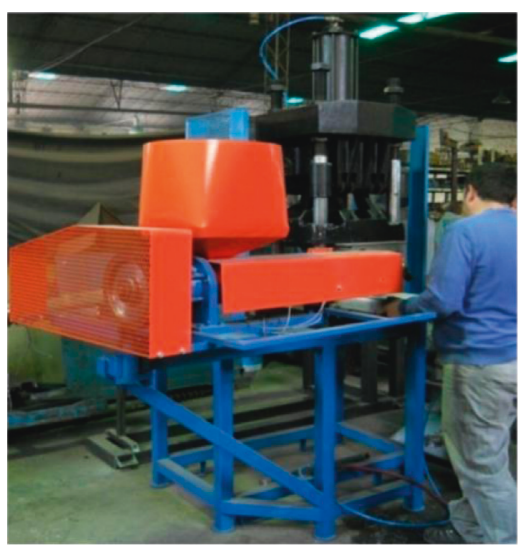

(a)

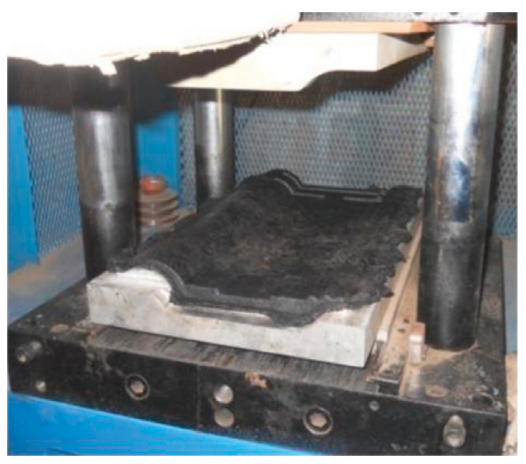

(c)

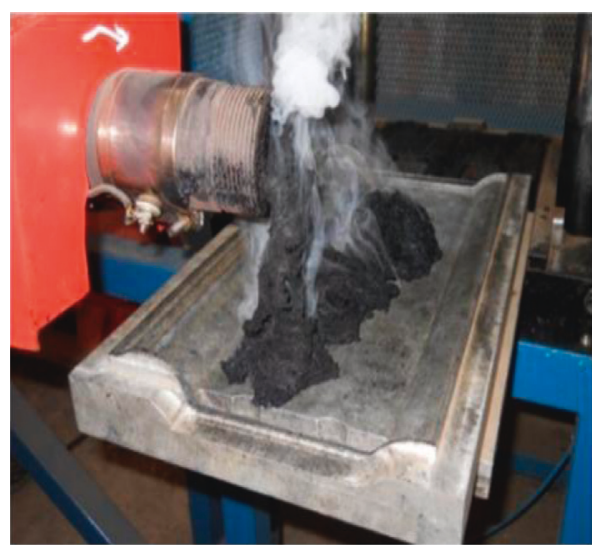

(b)

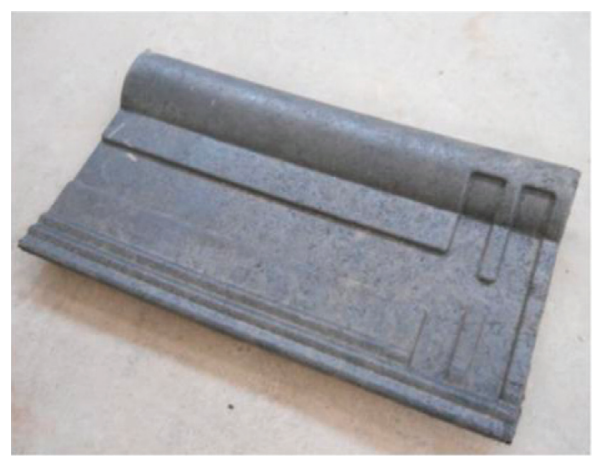

(d)

FiguRE 6: Extruder and pressing machine (a), filling the mold with the mixture (b), thermomolding of the component (c), and finished roofing tile (d).

roofing tile. The test was performed under Standard IRAM 12528-1. Place of realization: CINTEMAC Laboratory, UTN Córdoba.

(2) Specific weight: the roofing tile made from recycled materials has a lower specific weight than the other building elements: $87 \%$ less than the zinc sheet, $57 \%$ less than the concrete roofing tile, and $43 \%$ lower than the ceramic roofing tile. Place of realization: CINTEMAC Laboratory, UTN Córdoba.

(3) Thermal conductivity: the roofing tile made from recycled materials has a lower coefficient of thermal conductivity than the other building elements: $99.4 \%$ less than the zinc sheet, $72.5 \%$ less than the concrete roofing tile, and $49.2 \%$ less than the ceramic roofing tile.

(4) Place of realization: CINTEMAC Laboratory, UTN Córdoba. The data of the thermal conductivity coefficients of the concrete and ceramic roofing tiles and of the zinc sheets were taken from information provided by the manufacturers of the products of Córdoba.

(5) Permeability to air: the roofing tile made from recycled materials has a coefficient of permeability to the air, kT, much lower than the other roofing tiles. Zinc sheets are impervious to air. See in Figure 7 the permeability coefficient values, $\mathrm{kT}$, of the different types of constructive elements according to the surface finishes. Place of realization: CINTEMAC Laboratory, UTN Córdoba. The coefficients of permeability to air of the concrete and ceramic roofing tiles were taken from Table A6 of Annex A of IRAM Standard 11,601. Take into account that the unit of these coefficients is $\left(10-16 \mathrm{~m}^{2}\right)$.

See Table 3 for the classification of concrete roofing tiles according to the coefficients of permeability to air (Swiss Standard SIA 262/1-E10).

(6) Permeability to water vapor: all the analyzed constructive elements comply with IRAM Standard 11632-1 for concrete roofing tiles, which states that no drops of water should be released on the underside of the roofing tiles during the test. Place of realization: CINTEMAC laboratory, UTN Córdoba.

(7) Impact resistance: the roofing tile made from recycled materials and the concrete roofing tile have a satisfactory result in this test, complying with the IRAM Standard 12528-2, which establishes that, after having carried out the test, the roofing tile must not break or present defects such as blistering, splintering, cratering, burr damage, surface fissure, superficial microcracking of enamel, slip (quartet), or burr. 
TABLE 2: Technical properties of constructive elements for house cover.

\begin{tabular}{|c|c|c|c|c|c|}
\hline \multirow[b]{2}{*}{ Properties } & \multirow[b]{2}{*}{ Units } & \multicolumn{4}{|c|}{ Types of constructive elements for house cover } \\
\hline & & Zinc sheets & Concrete roofing tiles & Ceramic roofing tiles & $\begin{array}{l}\text { CEVE roofing tiles made } \\
\text { from recycled materials }\end{array}$ \\
\hline \multirow{3}{*}{ Dimensions } & \multirow{3}{*}{$\mathrm{mm}$} & Length: 12,800 & Length: 420 & Length: 423 & Length: 408 \\
\hline & & Width: 1086 & Width: 331 & Width: 248 & Width: 230 \\
\hline & & $\begin{array}{l}\text { Thickness on } \\
\text { average: } 1\end{array}$ & Thickness on average: 20 & Thickness on average: 15 & Thickness on average: 15 \\
\hline Mass & $\mathrm{kg}$ & 91.0 & 4.80 & 2.68 & 1.29 \\
\hline Specific weight & $\left(\mathrm{kg} / \mathrm{m}^{3}\right)$ & 7144 & 2200 & 1650 & 925 \\
\hline Weight per $\mathrm{m}^{2}$ & $\left(\mathrm{~kg} / \mathrm{m}^{2}\right)$ & 6.46 & 48.00 & 37.52 & 19.35 \\
\hline Thermal conductivity & $\left(\mathrm{W} / \mathrm{m}^{2} \cdot{ }^{\circ} \mathrm{C}\right)$ & 56.00 & 1.20 & 0.65 & 0.33 \\
\hline Permeability to air & $\left(10^{-16} \mathrm{~m}^{2}\right)$ & 0 & $\begin{array}{c}3.1 \geq \mathrm{kT} \leq 6.8 \\
\text { Depending on the surface } \\
\text { finish }\end{array}$ & $\begin{array}{l}0.054 \geq \mathrm{kT} \leq 3.1 \\
\text { Depending on the surface } \\
\text { finish }\end{array}$ & $\mathrm{kT}=0.001$ \\
\hline $\begin{array}{l}\text { Permeability to water } \\
\text { vapor }\end{array}$ & & Satisfactory & Satisfactory & Satisfactory & Satisfactory \\
\hline $\begin{array}{l}\text { Hard impact } \\
\text { resistance }\end{array}$ & & Satisfactory & Satisfactory & Nonsatisfactory & Satisfactory \\
\hline Flexural resistance & & Satisfactory & Satisfactory & Satisfactory & Satisfactory \\
\hline Resistance to freezing & & Satisfactory & Satisfactory & Satisfactory & Satisfactory \\
\hline Water absorption & $\%$ & 0 & 3.5 & 10 & 0.3 \\
\hline Resistance to aging & & Satisfactory & Satisfactory & Satisfactory & Satisfactory \\
\hline
\end{tabular}

The roofing tile made from recycled materials surpasses the ceramic roofing tile in this test, which presents superficial defects such as craters, chipping, and so on after the test. It is known that the ceramic roofing tile does not withstand a strong hail. Place of realization: Laboratory of Structures of the FCEFyN of the UNC.

(8) Flexural resistance: all the analyzed constructive elements have a satisfactory result in this test, performed under the IRAM 12528-2 Standard for concrete roofing tiles.

The roofing tile made from recycled materials is very flexible; consequently it resists higher loads than the ceramic and concrete roofing tiles, but with excessive deformation, which is not acceptable due to the conditions of support. The flexural resistant test must be stopped not by the breaking of the piece but by the deformation of the piece. The ceramic roofing tile resists a maximum load of $1000 \mathrm{~N}$. The concrete roofing tile resists a maximum load of $3200 \mathrm{~N}$, complying with the IRAM Standard that states that none of the roofing tiles should break under a load less than or equal to $1200 \mathrm{~N}$. Place of realization: Laboratory of Structures of the FCEFyN of the UNC.

(9) Resistance to freezing: all the analyzed constructive elements comply with the IRAM Standard 11632-2 for concrete roofing tiles, which states that no deterioration or surface peeling should be observed after the test. Place of realization: CINTEMAC Laboratory, UTN Córdoba.

(10) Water Absorption: the roofing tile made from recycled materials has a lower water absorption rate than the other roofing tiles: $91 \%$ less than the concrete roofing tile and $97 \%$ less than the ceramic roofing tile.
Both the roofing tiles made from recycled materials and the concrete and the ceramic roofing tiles comply with the IRAM Standard 12528-03, which establishes that the tiles immersed in water for 24 hours shall not absorb a quantity of water greater than $15 \%$ of their respective masses in the dry state. The zinc sheet is not water absorbent. Place of realization: Laboratory of Structures of the FCEFyN of the UNC.

(11) Resistance to aging: All the analyzed elements are resistant to the action of UV rays and humidity, according to the tests carried out under ASTM D 4329:99 and ASTM G154:04. The postaging flexural resistance and hard impact tests were performed to compare both values (before and after aging).

The test lasted 6 weeks, equivalent to 2 years exposed to the weather elements, in a climatic zone like Córdoba. Place of realization: Laboratory of Structures of the FCEFyN of the UNC.

4.2. Calculation of Thermal Transmittance, $K$. The calculation of the thermal transmittance coefficient, $K$, was performed for the four considered alternatives, with different types of constructive element for house cover. The calculation was made for the climatic zone of Córdoba, which is classified as Zone III A, Temperate Dry. The $K$ coefficients are shown in Table 4.

4.2.1. Discussion of Results on Thermal Performance of the Four Alternatives. The four alternatives comply with the Standard: Level B (average level) required by Argentine national law number 13,059 and IRAM 11605 standard; Conditions of habitability in buildings. Maximum values of thermal transmittance in opaque enclosures. Chapter: Maximum permissible transmittance for roofs:summer 


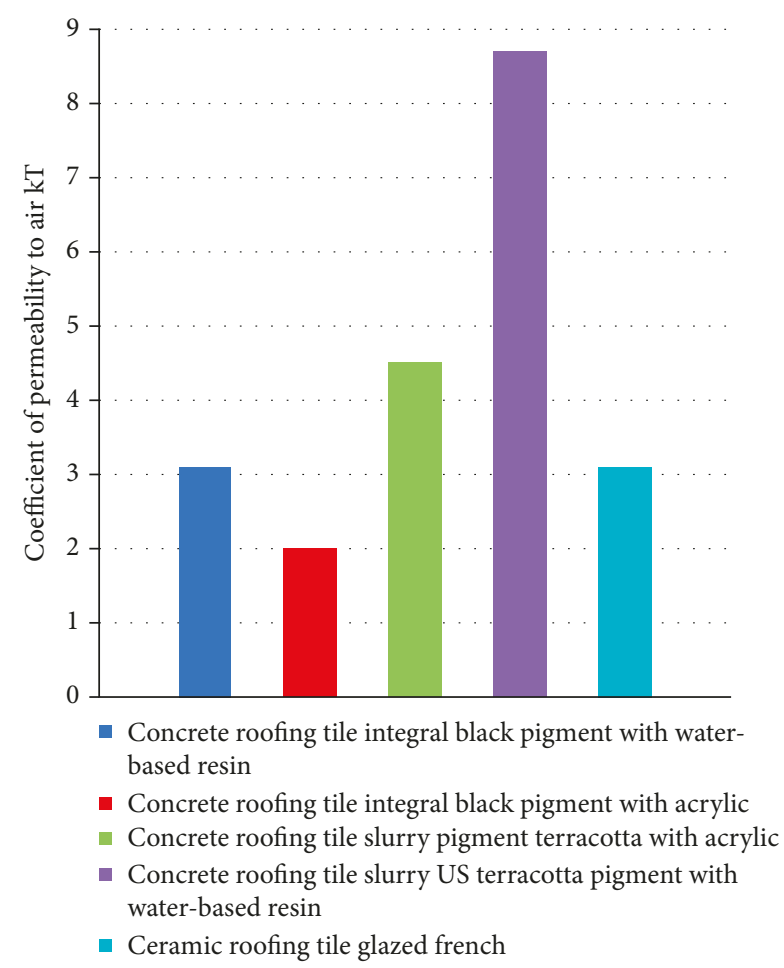

Figure 7: Coefficients of permeability to air in constructive elements for house cover. Zinc sheet, roofing tile from recycled materials (CEVE), concrete roofing tile with terracotta pigment integral with water-based resin, ceramic roofing tile unglazed colonial, and ceramic roofing tile unglazed French have a kT value close to zero.

TABLE 3: Classification of concrete roofing tiles according to the coefficients of permeability to air (Swiss Standard SIA 262/1-E10).

\begin{tabular}{lcc}
\hline Class & kT permeability $\left(10^{-16} \mathrm{~m}^{2}\right)$ & Permeability \\
\hline PK5 & $>10$ & Very high \\
PK4 & $1.0-10$ & High \\
PK3 & $0.1-1.0$ & Moderate \\
PK2 & $0.01-0.1$ & Low \\
PK1 & $<0.01$ & Very low \\
\hline
\end{tabular}

condition. For required Level B, the coefficient $\mathrm{K}$ must not exceed the value of 0.72 . In the case of the cover with zinc sheets, it complies to the limit with the Standard.

The thermal transmittance $\mathrm{K}$ of the option 4 with roofing tiles made from recycled materials is slightly higher than the other types of cover. However, we see in Table 1 that the thermal conductivity of the roofing tile made from recycled materials $\left(0.33 \mathrm{~W} / \mathrm{m}^{2} .{ }^{\circ} \mathrm{C}\right)$ is much lower than the other constructive elements:

(i) It is $99.4 \%$ lower than the zinc sheet $\left(56.00 \mathrm{~W} / \mathrm{m}^{2} \cdot{ }^{\circ} \mathrm{C}\right)$.

(ii) It is $72 \%$ lower than the concrete roofing tile $\left(1.20 \mathrm{~W} / \mathrm{m}^{2} \cdot{ }^{\circ} \mathrm{C}\right)$.

(iii) It is $50.7 \%$ lower than the ceramic roofing tile $\left(0.65 \mathrm{~W} / \mathrm{m}^{2} \cdot{ }^{\circ} \mathrm{C}\right)$.

To conclude, the major contribution to thermal resistance of the house cover is given by the thermal insulation layer and its thickness. Thus, the constructive element of cover (zinc sheets, ceramic roofing tiles, concrete roofing tiles, or rubber and plastic roofing tiles) is not decisive for the thermal performance of the house cover system.

On the other hand, it is recognized that, in many cases, it is not possible for users of social housing to have a ceiling with adequate thermal insulation (usually a layer of expanded polystyrene or glass wool), at an early stage of housing. It is common to begin to inhabit the dwelling with a cover made with zinc sheets, without insulating ceilings, because it is the most economical alternative; and later when the economic situation of the users allows, the thermal insulating ceiling is added.

This economic option does not comply in the initial stage with the current regulations regarding the coefficient of thermal transmittance (this coefficient $\mathrm{K}$ should not exceed the value of 0.72 in a climate like that in Córdoba). And it also has the problem of moisture condensation.

In the province of Córdoba, according to data from the National Population Households and Housing Census of 2010 [16], there are a total of 18,181 homes with zinc sheets as house cover; only 8,327 of them have thermal insulation ceilings (46\%), and 9,852 do not have thermal insulating ceilings (the remaining 54\%). And there are a total of 35,070 homes with roofing tiles; only 23,985 of them have thermal insulating ceilings ( $68 \%$ ), and 11,085 do not have insulating ceilings (the remaining 32\%). Please see the data presented in Table 1.

It follows that in an initial stage of housing, in which there is no possibility of having a thermal insulating ceiling, the housing that is covered with roofing tiles made from recycled materials is more convenient from the point of view of the thermal insulation. When the house is finished, if it has a thermal insulating ceiling, practically the four alternatives have the same thermal insulation: zinc sheets, ceramic roofing tiles, concrete roofing tiles, or roofing tiles made from recycled materials.

\section{Prices of the Compared Constructive Elements for House Cover}

Table 5 shows the prices of the compared constructive elements for house cover. The prices of the zinc sheet and the concrete and ceramic tiles were consulted to Zarate trade (of Córdoba). Date: 13/01/2017.

The price of the roofing tile made from recycled materials was calculated in CEVE. Direct costs (materials and labor), indirect costs (administration, taxes and services, equipment amortization, and maintenance), and a profit (profit for the entrepreneur) have been considered in this calculation.

Data of local materials and labor prices were used for the calculation.

The used equipment was of low performance, appropriated for a laboratory scale production, consisting of an extruder and press of molding that allows making a roofing tile every 15 minutes. Using this equipment, the unit price of this roofing tile is USD \$ 3.3, value updated at January 2017.

But if adequate equipment would be used for a larger scale, with an extruder and mold press that would allow a production of 4 roofing tiles every 15 minutes (simply with 
TABLE 4: Thermal transmittance coefficients, $K$, for different types of house cover.

\begin{tabular}{|c|c|c|c|c|}
\hline \multirow{2}{*}{ Type of house cover } & \multicolumn{3}{|c|}{$\begin{array}{l}\text { IRAM Norm (winter design } \\
\text { temperature }=-4.3^{\circ} \mathrm{C} \text { ) }\end{array}$} & \multirow{2}{*}{$K$ calculated for each case $\left(\mathrm{W} / \mathrm{m}^{2} \mathrm{~K}\right)$} \\
\hline & $\begin{array}{c}\text { A } \\
0.28\end{array}$ & $\begin{array}{l}\text { Sugerido } \\
0.50\end{array}$ & $\begin{array}{c}\mathrm{B} \\
0.72 \\
\end{array}$ & \\
\hline (1) With zinc sheets & \multicolumn{3}{|c|}{ It verifies level $B$} & 0.725 \\
\hline (2) With ceramic roofing tiles & \multicolumn{3}{|c|}{ It verifies level B } & 0.71 \\
\hline (3) With concrete roofing tiles & \multicolumn{3}{|c|}{ It verifies level B } & 0.72 \\
\hline $\begin{array}{l}\text { (4) With roofing tiles made from recycled rubber and } \\
\text { plastic }\end{array}$ & \multicolumn{3}{|c|}{ It verifies level B } & 0.70 \\
\hline
\end{tabular}

TABle 5: Prices of constructive elements for house cover.

\begin{tabular}{|c|c|c|c|c|}
\hline Type of constructive element & Brand name & USD/Unit & Quantity $/ \mathrm{m}^{2}$ & $\mathrm{USD} / \mathrm{m}^{2}$ \\
\hline (1) Zinc sheet & & 118.2 & 0.071 & 8.3 \\
\hline (2) Unglazed red ceramic roofing tile & Losa Olavarria & 1.0 & 14 & 14.8 \\
\hline (3) Glazed red ceramic roofing tile & Losa Olavarria & 1.5 & 14 & 21.8 \\
\hline (4) Satin black ceramic roofing tile & Losa Olavarria & 2.5 & 14 & 35.0 \\
\hline (5) Glazed black ceramic roofing tile & Losa Olavarria & 2.5 & 14 & 35.0 \\
\hline (6) Glazed blue ceramic roofing tile & Losa Olavarria & 2.6 & 14 & 37.6 \\
\hline (7) Glazed green ceramic roofing tile & Losa Olavarria & 2.4 & 14 & 34.4 \\
\hline (8) Unglazed concrete (red/black/gray) roofing tile & Tejalite & 1.0 & 10 & 10.6 \\
\hline $\begin{array}{l}\text { (9) Unglazed concrete (blue/green/purple) roofing } \\
\text { tile }\end{array}$ & Tejalite & 1.25 & 10 & 12.5 \\
\hline $\begin{array}{l}\text { (10) Black roofing tile made from recycled rubber and } \\
\text { plastic }\end{array}$ & CEVE & 2.0 & 15 & 30.2 \\
\hline
\end{tabular}

a larger molding tray), the unit price of this roofing tile drops significantly, to USD \$2.0, value updated at January 2017. In Table 5 this value has been used.

See the comparison of prices in Figure 8.

\subsection{Conclusions about the Prices of the Compared Constructive} Elements for House Cover. The price per $\mathrm{m}^{2}$ of the roofing tile made from recycled materials is $14 \%$ lower than that of the glazed black ceramic roofing tile (the most similar in traditional roofing tiles), $72 \%$ higher than that of the zinc sheet, $65 \%$ higher than that of the concrete tile, and $27 \%$ higher than that of the glazed red ceramic roofing tile.

The most economical option is to use the zinc sheet, but it has some technical disadvantages in the initial stage of social housing, in which in general there is no ceiling that provides the necessary thermal and acoustic insulation and that avoids the problem of condensation of moisture.

Because of its low cost, this option is generally used in affordable housing or in large roofs, for example in industrial sheds. But with a ceiling with adequate thermoacoustic insulation, it is also used in housing for the middle and upper social classes.

\section{Norms}

Norms used in this work are as follows:

(i) IRAM 11601, Aislamiento térmico de edificios. Métodos de cálculo. Propiedades térmicas de los componentes y elementos de construcción en

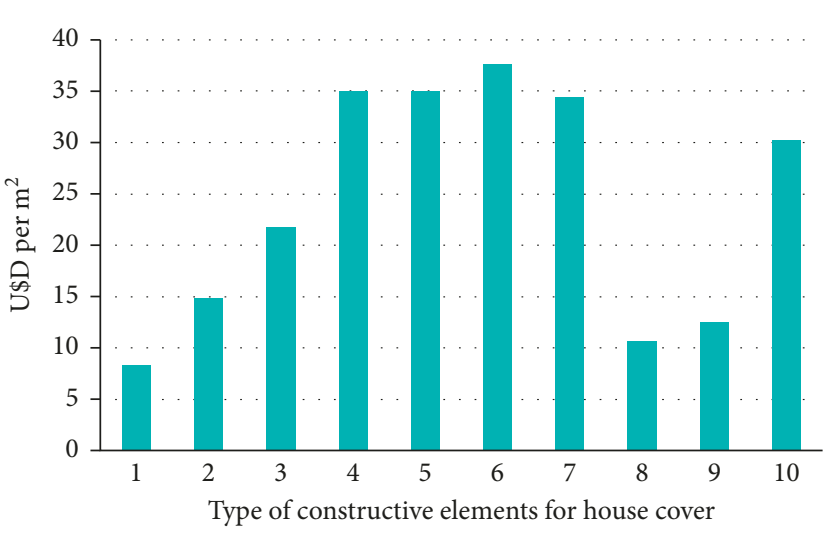

FIgURE 8: Comparative price chart of construction elements for house cover.

régimen estacionario. Instituto Argentino de Normalización y Certificación, 2002.

(ii) IRAM 11603, Acondicionamiento térmico de edificios. Clasificación bioambiental de la República Argentina. Instituto Argentino de Normalización y Certificación, 2012.

(iii) IRAM 11605, Acondicionamiento térmico de edificios. Condiciones de habitabilidad en edificios. Valores máximos de transmitancia térmica en cerramientos opacos. Instituto Argentino de Normalización y Certificación, 1996.

(iv) IRAM 11632-1, Tejas y accesorios de hormigón. Requisitos. Instituto Argentino de Normalización y Certificación, 2001. 
(v) IRAM 11632-2, Tejas y accesorios de hormigón. Métodos de ensayo. Instituto Argentino de Normalización y Certificación, 2001.

(vi) IRAM 12528-1, Tejas cerámicas de encastre. Parte 1: Definiciones y requisitos. Instituto Argentino de Normalización y Certificación, 2003.

(vii) IRAM 12528-2, Tejas cerámicas de encastre. Parte 2: Métodos de ensayo. Instituto Argentino de Normalización y Certificación, 2003.

(viii) ASTM D4329-99, Standard Practice for Fluorescent UV Exposure of Plastics, ASTM International, West Conshohocken, PA, 1999.

(ix) ASTM G154-04, Standard Practice for Operating Fluorescent Light Apparatus for UV Exposure of Nonmetallic Materials, ASTM International, West Conshohocken, PA, 2004.

(x) SIA 262/1, Concrete Construction-Additional Specifications. Annex E: Air Permeability in Structures. Swiss Standard, 2003.

\section{Final Conclusions}

The thermal performance of a house cover with the roofing tile made from recycled materials developed in CEVE is better than that of other alternatives with traditional roofing (zinc sheets and ceramic or concrete roofing tiles) at an early stage of the house, when is not possible to have an insulating ceiling. The reason of this better performance is that its thermal conductivity is low $(99.4 \%$ lower than the zinc sheet, $72 \%$ lower than the concrete roofing tile, and $50.7 \%$ lower than the ceramic roofing tile). When the houses are finished, if they have a thermal insulating ceiling, they have practically the same thermal insulation in the four alternatives: with zinc sheets, with ceramic roofing tiles, with concrete roofing tiles, or with roofing tiles made from recycled materials.

With regard to the price of the components, the price per $\mathrm{m}^{2}$ of the roofing tile made from recycled materials developed in CEVE is $14 \%$ lower than the glazed black ceramic roofing tile (the most similar in traditional roofing tiles), but higher than other options such as the zinc sheet. It should be taken into account, when choosing the option of constructive element for a house cover, that the roofing tile made from recycled materials developed in CEVE has several advantages over the other compared traditional components, technical advantages. Since it has more thermal insulation, it is more resistant to flexion, hail, and freezing, it is less permeable to water and to air, it is less water absorbent, and it has a lower specific weight; and it also has ecological advantages because it is made from recycled waste, collaborating in the decontamination of the environment.

\section{Conflicts of Interest}

The authors declare that they have no conflicts of interest.

\section{Acknowledgments}

The authors wish to thank the Experimental Center for Economical Housing (CEVE) and the National Council of Scientific and Technological Research (CONICET) by grant to Project PIP 1122015. María Paz Sánchez Amono and Julián González Laría gratefully acknowledge the receipt of a fellowship from CONICET.

\section{References}

[1] P. Sapirstein, "How the corinthians manufactured their first roof tiles," Hesperia: The Journal of the American School of Classical Studies at Athens, vol. 78, no. 2, pp. 195-229, 2009.

[2] D. E. Friesem, G. Tsartsidou, P. Karkanas, and R. Shahack-Gross, "Where are the roofs? A geo-ethnoarchaeological study of mud brick structures and their collapse processes, focusing on the identification of roofs," Archaeological and Anthropological Sciences, vol. 6, no. 1, pp. 73-92, 2014.

[3] E. Schunck, H. J. Oster, R. Barthel, and K. Kiessl, Roof Construction Manual: Pitched Roofs, Walter de Gruyter, Berlin, Germany, 2003.

[4] P. Berdahl, H. Akbari, R. Levinson, and W. A. Miller, "Weathering of roofing materials-An overview," Construction and Building Materials, vol. 22, no. 4, pp. 423-433, 2008.

[5] C. Kibert, "CIB-TG16," in Proceedings of the First International Conference on Sustainable Construction, Tampa, FL, USA, November 1994.

[6] M. Zhang, "Slate made with plastic mix (PVC; CPVC; PVDC; ABS; ASA y EVA)," European Patent, 2001.

[7] F. Bacon, W. Holland, and J. Tikalsky, "Roofing materials made with nylon fiber composites," US20050170141 A1, 2005.

[8] B. Boor, "Composite material roofing structure," WO 2009152213 A1, 2009.

[9] J. Fiorelli, J. A. B. Morceli, R. I. Vaz, and A. A. Dias, “Avaliação da eficiência térmica de telha reciclada à base de embalagens longa vida," Revista Brasileira de Engenharia Agrícola e Ambiental, vol. 13, no. 2, pp. 204-209, 2009.

[10] F. J. Navarro, P. Partal, F. J. Martínez-Boza, and C. Gallegos, "Novel recycled polyethylene/ground tire rubber/bitumen blends for use in roofing applications: thermo-mechanical properties," Polymer Testing, vol. 29, no. 5, pp. 588-595, 2010.

[11] R. Gaggino, M. J. Positieri, P. Irico, J. Kreiker, R. Arguello, and M. P. A. Sánchez, "Ecological roofing tiles made with rubber and plastic wastes," Advanced Materials Research, vol. 844, pp. 458-461, 2014.

[12] Gobierno de la ciudad de Buenos Aires-Ministerio de Ambiente y Espacio Público, Informe Anual de Gestión Integral de Residuos Sólidos Urbanos, Buenos Aires, Argentina, 2015.

[13] A.-C. Albertsson and S. Karlsson, "The influence of biotic and abiotic environments on the degradation of polyethylene," Progress in Polymer Science, vol. 15, no. 2, pp. 177-192, 1990.

[14] L. Rehak, K. Potarsky, and R. Poliak, "Argentina comienza a reciclar neumáticos," Saber Como, vol. 91, p. 5, 2010.

[15] A. Beers, Hazardous Waste Incineration: The Cement Kiln Option, Commission on Toxic Substances and Hazardous Wastes, New York, NY, USA, 1987.

[16] Instituto Nacional de Estadísticas y Censos-INDEC, Censo de Población del año 2010. Tipos de Cubierta Empleados en la Provincia de Córdoba, Caba, Argentina, 2010.

[17] G. E. Gonzalo and V. M. Nota, Manual de Arquitectura Bioclimática, Nobuko, Buenos Aires, Argentina, 2nd edition, 2003. 


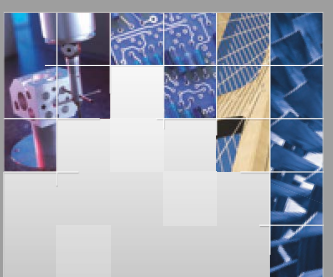

\section{Enfincering}
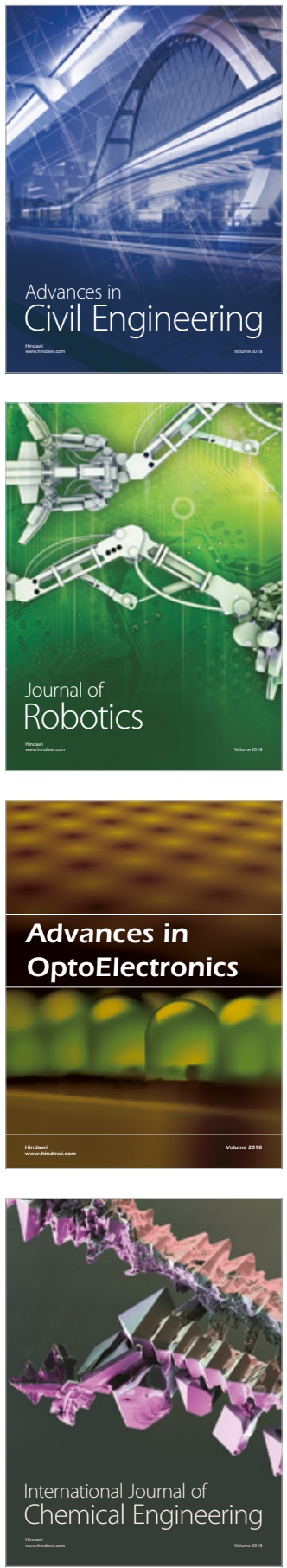

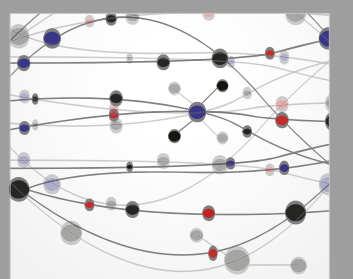

\section{Rotating \\ Machinery}

The Scientific World Journal

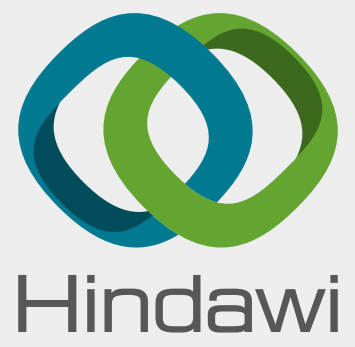

Submit your manuscripts at

www.hindawi.com
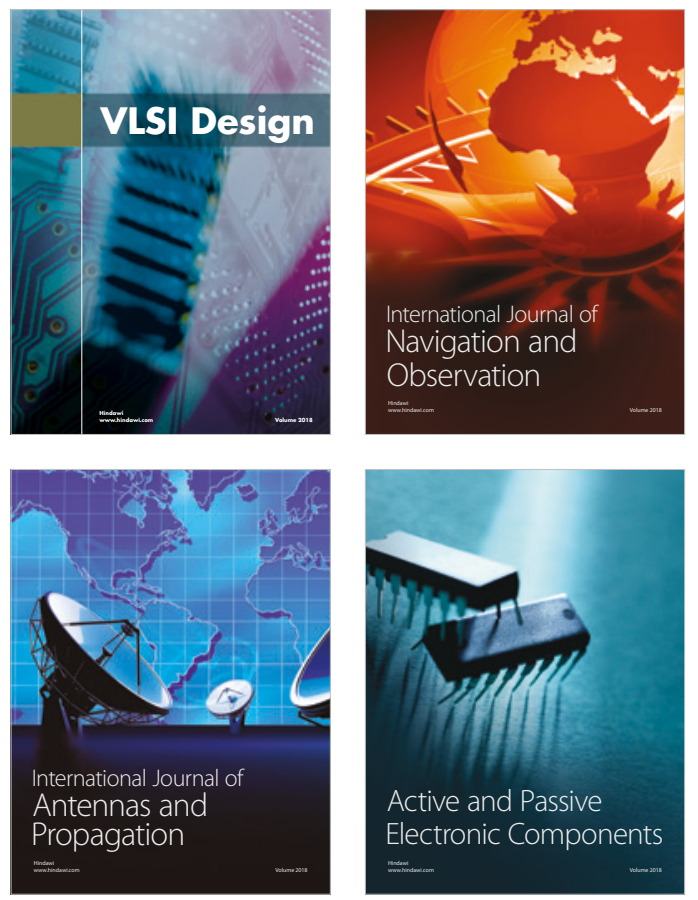
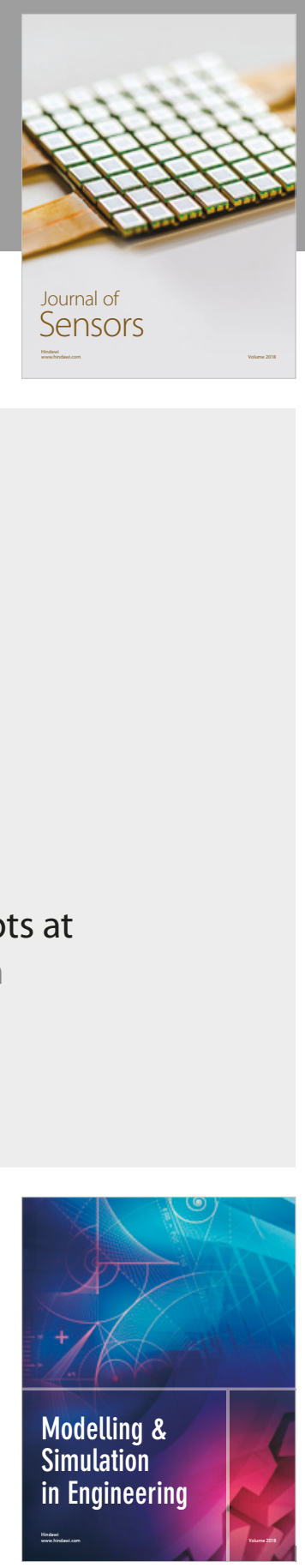

\section{Advances \\ Multimedia}
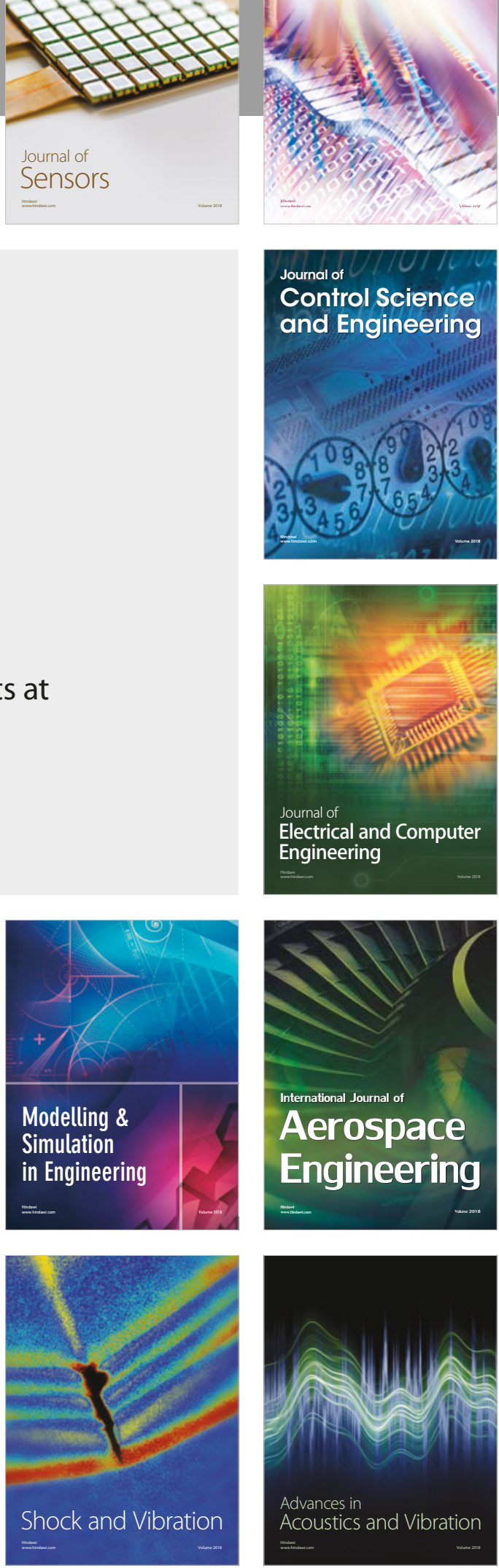